TITLE:

\title{
Ligand-Mediated G-Quadruplex Induction in a Double-Stranded DNA Context by Cyclic Imidazole/Lysine Polyamide
}

\section{$\operatorname{AUTHOR}(\mathrm{S}):$}

Asamitsu, Sefan; Li, Yue; Bando, Toshikazu; Sugiyama, Hiroshi

\section{CITATION:}

Asamitsu, Sefan ... [et al]. Ligand-Mediated G-Quadruplex Induction in a Double-Stranded DNA Context by Cyclic Imidazole/Lysine Polyamide. ChemBioChem 2016, 17(14): 1317 1322

\section{ISSUE DATE:}

2016-07-15

URL:

http://hdl.handle.net/2433/230877

\section{RIGHT:}

This is the accepted version of the following article: [Sefan Asamitsu, Yue Li, Toshikazu Bando, Hiroshi

Sugiyama.Ligand - Mediated G - Quadruplex Induction in a Double - Stranded DNA Context by Cyclic Imidazole/Lysine Polyamide. ChemBioChem (2016), 17, 14, 1317-1322], which has been published in final form at

https://doi.org/10.1002/cbic.201600198. This article may be used for non-commercial purposes in accordance with Wiley Terms and Conditions for Self-Archiving.; The full-text file will be made open to the public on 18 July 2017 in accordance with publisher's 'Terms and Conditions for Self-Archiving'; This is not the published version. Please cite only the published version.; この論文は出版社版でありません。引用の際には出版社版をご確認ご利用ください。 


\section{Ligand-mediated G-quadruplex Induction in a Double-stranded DNA Context by Cyclic Imidazole/Lysine Polyamide}

\begin{abstract}
G-quadruplex (G4) DNA is often observed as a DNA secondary structure in guanine-rich sequences and is thought to be relevant to pharmacological and biological events. Therefore, G4 ligands have attracted great attention regarding potential anticancer therapies or molecular probe applications. In the present study, we designed cyclic imidazole/lysine polyamide (cIKP) as a new class of G4 ligand, which was readily synthesized without time-consuming column chromatography. CIKP enables the selective recognition of particular G4 structures with low nanomolar affinity. Moreover, cIKP exhibited the ability to induce G4 formation on the promoter of G4containing DNAs in the context of stable double-stranded DNA (dsDNA) under molecular crowding conditions. This cIKP may be applicable as a molecular probe for the detection of potential G4forming sequences in dsDNA.
\end{abstract}

Sefan Asamitsu, ${ }^{[a]}$ Yue Li, ${ }^{[a]}$ Toshikazu Bando, ${ }^{* a]}$ and Hiroshi Sugiyama*[a,b]

\section{Introduction}

G-quadruplex (G4) DNA is the higher-order structure of fourstranded nucleic acids including several G-quartets comprising four planar guanines that stabilize each other via Hoogsteen hydrogen bonding. G4 structures can be formed in G-rich sequences, and monovalent metal cations $\left(\mathrm{K}^{+}\right.$or $\left.\mathrm{Na}^{+}\right)$reinforce the stability of such structures. ${ }^{[1]}$ It has been shown that G4forming sequences are widely present in human genomes, notably in the promoter and $5^{\prime}$-UTR regions of genes that are involved in cellular proliferation or are relevant to several diseases, as well as in telomere sequences. ${ }^{[2]}$ Hence, G4 structures have attracted great attention regarding biological events, including gene alteration, ${ }^{[3 a, b]}$ epigenetic regulation, ${ }^{[3 c]}$ genome stability, ${ }^{[3 d]}$ and targets for these therapies. ${ }^{[3 e-g]}$ To date, several synthetic molecules have been reported as G4 ligands, such as flat aromatic, macrocyclic, and crescent-shaped compounds. ${ }^{[4]}$ In particular, the fact that a naturally occurring macrocycle, telomestatin, exhibits telomerase-inhibition activity by binding to telomeric G4 structures has accelerated attempts to study synthetic macrocycles for the direct targeting of these structures, aiming to develop potential anticancer therapies or molecular probe applications. ${ }^{[3 \mathrm{~d}, 5]}$ For example, furan-based cyclic

[a] S. Asamitsu, Y. Li, Dr. T.Bando, Prof. H. Suigiyama Department of Chemistry, Graduate School of Science Kyoto University Kitashirakawa-Oiwakecho Sakyo-ku, Kyoto 606-8502 (Japan) E-mail: hs@kuchem.kyoto-u.ac.jp (H. Sugiyama), Bando@kuchem.kyoto-u.ac.jp (T. Bando).

[b] Prof. H. Sugiyama Institute for Integrated Cell-Material Sciences (WPI-iCeMS) Kyoto University Yoshida-Ushinomiyacho Sakyo-ku, Kyoto 606-8501 (Japan).

Supporting information for this article is given via a link at the end of the document. (a)

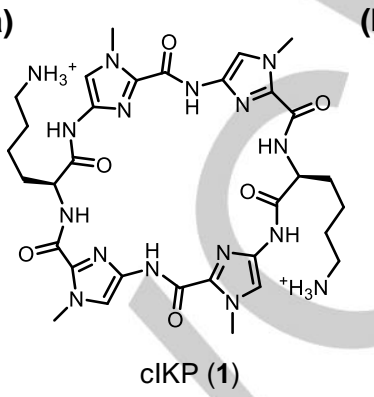

(b)

Figure 1. Chemical structures of clKP (1) (a) and TMPyP4 (b)

oligopeptides were shown to be highly selective for G4 structures, and some cyclic oligopeptides (24-membered rings) suppressed the mRNA expression of the $c-M y c$ oncogene, the promoter of which contains G4-forming sequences. ${ }^{[6]} A$ cationic telomestatin derivative shows strong binding affinity for telomeric $\mathrm{G} 4$ over other G4 structures. ${ }^{[7]}$ In addition to these compounds, several macrocyclic compounds have been reported as G4 ligands, and, in some cases, G4 topology selectivity was successfully achieved. ${ }^{[3 b, 8]}$ Therefore, such macrocyclic structures are attractive scaffolds to achieve both binding affinity and selectivity for particular G4 structures.

For years, we have studied a synthetic DNA minor groove binder named pyrrole-imidazole polyamide (PIP). PIP was developed by Prof. Dervan and colleagues as a programmable DNA-binding molecule and distinctly recognized $A / T$ base parings and $G / C$ base parings with modest affinity and specificity. ${ }^{[9]}$ In the course of such PIP studies, we have reported that consecutive imidazole rings held together via amide bonds adopt a highly planar conformation, as estimated by density functional theory. ${ }^{[10]}$ In the present study, we designed cyclic Imidazole/Lysine Polyamide, clKP (1) as a new class of G4 ligand, which was readily synthesized and which enabled selective recognition of the particular G4s with higher binding affinity compared to TMPyP4, a well-studied G4-interactive compound (Figure 1). Furthermore, clKP exhibited the ability to induce G4 formation on the promoter G4 DNAs in the context of stable dsDNA under molecularly crowded conditions.

\section{Results and Discussion}

\section{Molecular design and synthesis}

Based on the above mentioned report, the imidazole moiety was selected as a key component for the molecular planarity of the structure, although other heteroaromatic rings were widely used to construct the planar backbones of most of the other macrocyclic G4 ligands. ${ }^{[4 a, 11]}$ The lysine residue was adopted as another core mainly because its positively charged side chains

For internal use, please do not delete. Submitted_Manuscript 


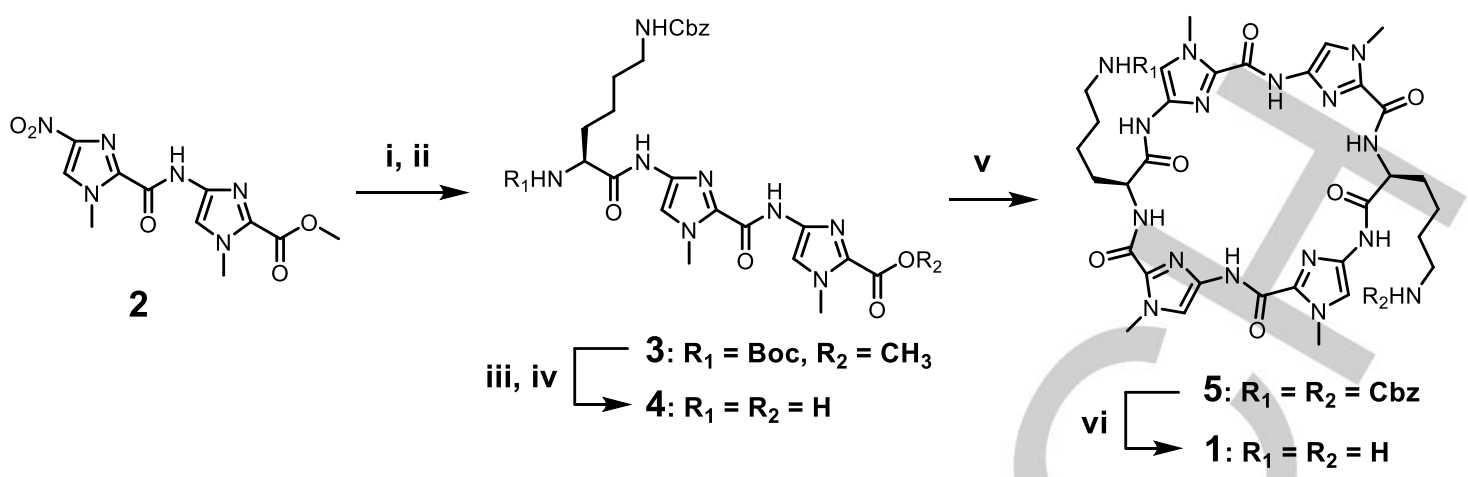

Scheme 1. Synthetic route of clKP (1) in solution-phase. Compound 2 was prepared from $\mathrm{NO}_{2}-\mathrm{I}-\mathrm{COCCl}$. Reagents and conditions; (i) $\mathrm{H}_{2}$, 10 wt\% $\mathrm{Pd} / \mathrm{C}$, AcOEt, $\mathrm{MeOH}$, rt. (ii) BocNH-Lys(Cbz)-OH, HCTU, DIEA, DMF, rt, $64 \%$ over two steps. (iii) $\mathrm{NaOH}, \mathrm{MeOH}, \mathrm{H}_{2} \mathrm{O}, 45{ }^{\circ} \mathrm{C}$. (iv) TFA, DCM, rt. (v) FDPP, DIEA, DMF, rt, 52\% over 3 steps. (vi) TfOH, TFA, rt, $98 \%$.

can electrostatically interact with the negatively charged phosphate backbone of the G4s. ${ }^{[2]}$ Although the incorporation of the two lysine moieties seems likely to sacrifice the high planarity of the molecule, the relatively flexible compound could mold into the surface of the G-quartet. ${ }^{[12]}$ CIKP (1) was synthesized as shown in Scheme 1. We successfully synthesized the target compound using a total of nine steps without any time-consuming chromatographic purification, with the exception of that of the final product. Moreover, although, generally, 2 or 3 days are necessary to finish the ring-closing step upon the construction of the macrocyclic backbone in low yield, ${ }^{[6,7,8 b]}$ the dimerization of the linear imidazole/lysine polyamide gave a better yield and reduced the reaction time. This may be attributed to internal $\mathrm{H}$-bond formation between the $\mathrm{N}$ of imidazole and the $\mathrm{H}$ of the adjacent amide. ${ }^{[10]}$ Three commonly used condensation agents, PyBOP, HCTU, and DPPA, were applicable to this dimerization reaction, with comparable yields achieved within $4 \mathrm{~h}$ (see Supporting Information).

(a)

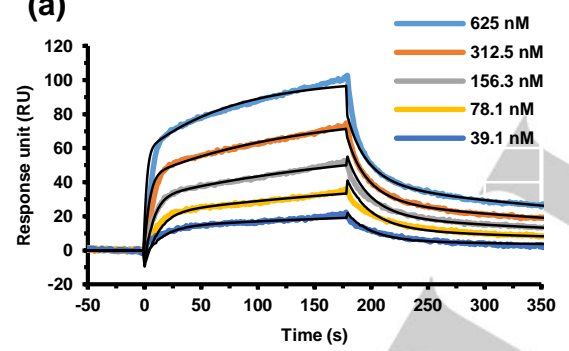

(d)

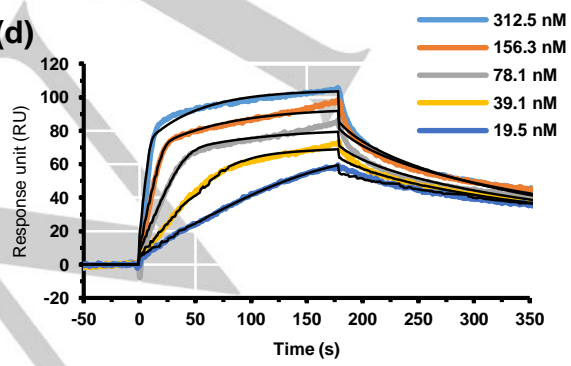

\section{SPR-binding assays}

To evaluate the binding properties of $\mathbf{1}$ for G4s and doublestranded DNAs (dsDNA) quantitatively, we performed an SPRbinding assay (Figure 2). ${ }^{[13]}$ We selected five DNAs harboring G4forming sequences located in a human telomere, and the promoter regions of the $c-M y c, c-k i t-1, c-k i t-2$, and BCL2 genes, which were studied well via quantitative analysis using SPRbinding assays (Table S1). ${ }^{[6,14]}$ The sensorgrams obtained for $c$ Myc or telomeric/c-kit-1/c-kit-2/BCL2 G4s were better fitted by a single-site or a two-site model, respectively, suggesting a $1: 1$ or 2:1 stoichiometry for the binding of $\mathbf{1}$ to $c-M y c$ or telomeric/c-kit1/c-kit-2/BCL2 G4s within optimized concentration ranges. These two fitting models include equations that reflect mass transfer limitation effect. The association rate $\left(k_{\mathrm{a}}\right)$, dissociation rate $\left(k_{\mathrm{d}}\right)$, and dissociation constant $\left(K_{\mathrm{D}}\right)$ for the interaction of 1 with the $\mathrm{G} 4$ DNAs are shown in Table 1. For telomeric/c-kit-1/c-kit-2/BCL2 G4s, 1 exhibited a preference for one site over the other. The kinetic parameters and dissociation constants for the weaker (b)

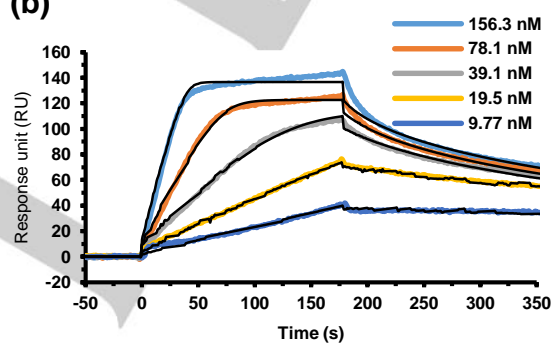

(c)

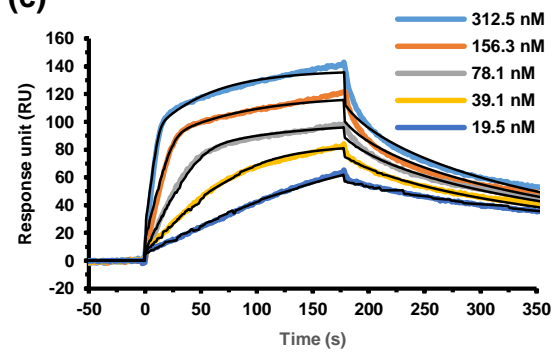

(e)

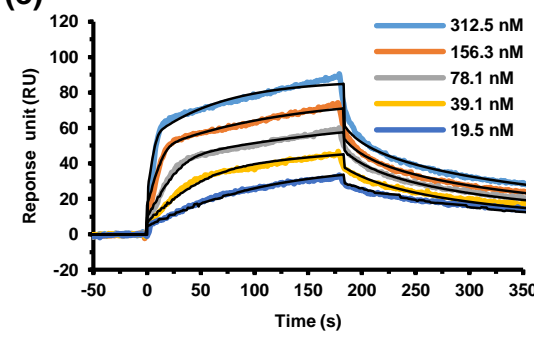

Figure 2. SPR-binding assays to evaluate the binding properties of cIKP (1). Each SPR sensorgram is fitted with an appropriate fitting model (black line). (a) SPR sensorgrams for interactions with telomere G4. (b) SPR sensorgrams for interactions with $c-M y c$ G4. (c) SPR sensorgrams for interactions with $c-k i t-1$ G4. (d) SPR sensorgrams for interactions with c-kit-2 G4. (e) SPR sensorgrams for interactions with BCL2 G4.

For internal use, please do not delete. Submitted_Manuscript 
Table 1. Values of the association rates $\left(k_{\mathrm{a}}\right)$ and dissociation rates $\left(k_{\mathrm{d}}\right)$ obtained from curve fittings of the sensorgrams, and dissociation constants $\left(K_{D}\right)$.

\begin{tabular}{cccc}
\hline & \multicolumn{3}{c}{$\operatorname{cIKP}(\mathbf{1})$} \\
\cline { 2 - 4 } DNA & $k_{\mathrm{a}}\left[\mathrm{M}^{-1} \mathrm{~s}^{-1}\right]$ & $k_{\mathrm{d}}\left[\mathrm{s}^{-1}\right]$ & $K_{\mathrm{D}}[\mathrm{nM}]$ \\
\hline Telomere $^{[a]}$ & $7.5 \times 10^{5}$ & $6.7 \times 10^{-2}$ & 90 \\
$c-M y c^{[b]}$ & $2.0 \times 10^{6}$ & $1.3 \times 10^{-2}$ & 6.2 \\
$c-k i t-f^{[a]}$ & $2.2 \times 10^{6}$ & $1.6 \times 10^{-2}$ & 7.4 \\
$c-k i t-2^{[a]}$ & $3.3 \times 10^{6}$ & $1.2 \times 10^{-2}$ & 3.8 \\
$B C L 2^{[a]}$ & $2.4 \times 10^{6}$ & $4.1 \times 10^{-2}$ & 17 \\
$\mathrm{dsDNA}$ & Few response & Few response & Few response \\
\hline
\end{tabular}

[a] Determined by fitting with a modified heterogeneous ligand-binding model (two-site binding model). [b] Determined by fitting with a $1: 1$ binding model with mass transfer.

binding sites were described in Table S2. Compound 1 showed higher affinity for $c-M y c(6.2 \mathrm{nM}), c-k i t-1(7.4 \mathrm{nM}), c-k i t-2(3.8 \mathrm{nM})$, and BCL2 (17 nM) G4s, whereas it had modest affinity for the telomeric G4 $(90 \mathrm{nM})$. This indicates that 1 has a 24-fold selectivity toward particular G4 structures (c-kit-2 vs telomeric G4s). Furthermore, a low response of $\mathbf{1}$ for duplex DNA (both GCrich and AT-rich sequences) was observed even at higher concentrations, indicating a significantly high selectivity toward G4 structures (Figure S1). Compared with the $K_{\mathrm{D}}$ values of TMPyP4 (Figure 1b), which were measured for some G4s using the SPR method, ${ }^{[8 \mathrm{~h}]} \mathbf{1}$ exhibited approximately 2 -fold and 5-10-fold higher binding affinities for telomeric G4s and cMyc/c-kit-1 G4s, respectively. Collectively, 1 showed high selectivity and low nanomolar affinity toward G4 compared with dsDNA and exhibited some modest selectivity toward particular G4s.

\section{CD spectra analysis}

Next, we performed a CD spectra analysis to investigate the binding behavior of 1 to G4 structures using c-Myc, c-kit-1, c-kit2, and BCL2 G4s (Table S1). CD titration using several concentrations of 1 revealed that 1 can recognize and bind to G4 structures and does not cause conformational changes upon binding (Figure S2). Moreover, the ability of $\mathbf{1}$ to form G4 structures was evaluated in the absence of $\mathrm{K}^{+}$(Figure S3). ${ }^{[15]}$ Regarding $c-M y c, c-k i t-2$, and BCL2 ssDNA, no significant differences were observed compared with the case of the presence of $\mathrm{K}^{+}$, suggesting that $\mathbf{1}$ forms the same $\mathrm{G} 4$ structures according to CD spectra (Figure S3a,c,d). ${ }^{[16]}$ Conversely, 1 exhibited a different behavior for c-kit-1 ssDNA, including the amplitude of the positive peak detected at $\sim 295 \mathrm{~nm}$ (Figure S3b). This suggests that $\mathbf{1}$ drives $c$-kit-1 ssDNA to form hybrid or antiparallel/parallel mixed G4s instead of the parallel structure. ${ }^{[16]}$ Those results demonstrate that $\mathbf{1}$ has the ability to form G4 structures from ssDNA.

\section{Induction of G4 formation in dsDNA context}

In living cells, genomic DNA is usually present as a double helix. We examined the binding properties of $\mathbf{1}$ for four G4s located in the promoter regions in the presence of their complementary strands. A previous pioneer work clearly reveled induction of $\mathrm{G} 4$ formation by a small molecule using the core G4-forming sequence and its complementary strand by gel electrophoresis. ${ }^{[17]}$

(a)

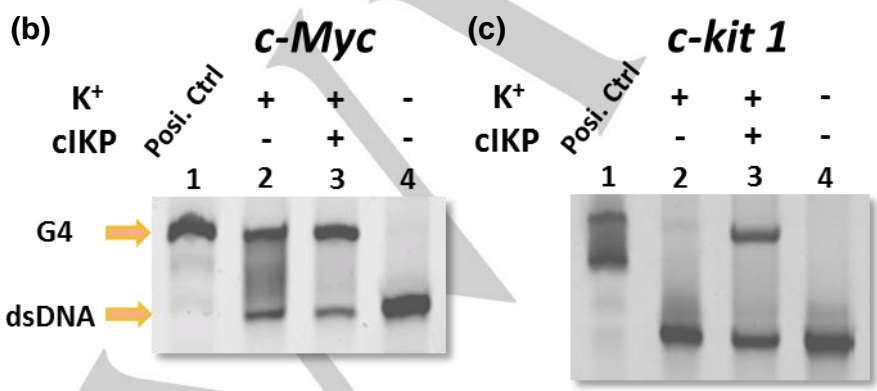

(d)

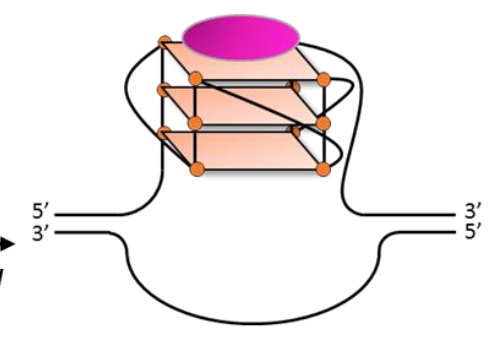

G4 DNA

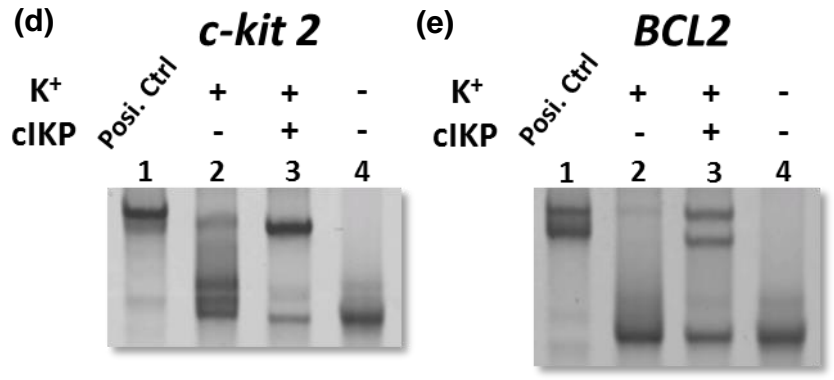

Figure 3. Induction of $\mathrm{G} 4$ formation by 1 in the presence of $\mathrm{KCl}$, as assessed by native gel electrophoresis. (a) Schematic representation of $\mathrm{G} 4$ induction by the ligand. (b) c-Myc dsDNA, (c) c-kit-1 dsDNA, (d) c-kit-2 dsDNA, and (e) BCL2 dsDNA. Lane 1 is a positive control for G4 formation bands. Lane 4 shows dsDNA formation bands. Note that the two bands showing G4 formation for c-kit-1 and BCL2 are attributable to several potential G4 conformations on each sequence. ${ }^{[19]}$

For internal use, please do not delete. Submitted_Manuscript 
To truly reflect and better understand G4 induction effect by 1 in the genomic DNA context, we employed DNAs that consisted of a single G4-forming sequence and two flanking duplex regions and their complementary DNAs, and conducted these experiments under molecularly crowded condition. ${ }^{[18]}$ DNAs including a single G4-forming sequence and their complementary DNAs were annealed in $40 \%$ (w/v) PEG 200 solution. The DNA solution was incubated at $37{ }^{\circ} \mathrm{C}$ for $30 \mathrm{~min}$ in the presence or absence of $\mathbf{1}$ and was then subjected to native gel electrophoresis. As positive controls, poly- $T$ sequences, with which the complementary sequences of G4-forming ones were replaced, were used to confirm the band showing the DNA containing a G4 on the gel (Table S1). Such G4-containing DNAs migrated behind the same sequences remaining in the dsDNA. ${ }^{[18]}$ The migration behavior of DNAs upon the addition of $\mathbf{1}$ are shown in Figure 3. Regarding the c-kit-1,c-kit-2, and BCL2 dsDNAs, G4s were almost not formed in the absence of $\mathbf{1}$, but migrated bands indicating G4 formation appeared after incubation with 1, with a mobility on the gel that corresponded to that of a positive control (Figure $3 c-e$ ). Note that two bands showing G4 for c-kit-1 and $B C L 2$ can be attributed to several potential $\mathrm{G} 4$ conformations on each sequence. ${ }^{[19]}$ Conversely, TMPyP4 did not exhibit the G4 induction effect under the same conditions containing the $P E G$ solution (Figure S4). Given that such G4 induction did not occur in the absence of PEG solution (Figure S5), $\mathbf{1}$ has the property of inducing G4 formation from the stable dsDNA under a molecular crowding condition. Regarding the $c-M y c$ dsDNA, G4 had already been formed in the absence of $\mathbf{1}$ and, therefore, it is difficult to observe the induction effect by 1 in the dsDNA context (Figure 3b). To circumvent this problem, we performed the same experiment in the absence of $\mathrm{KCl}$. Interestingly, even in the absence of $\mathrm{KCl}$, such induction of G4 formation by 1 was observed (Figure S6). This result also demonstrates the induction ability of $\mathbf{1}$ to form G4 structures in a stable dsDNA context. The dose-dependency observed in Figure S6 was not significant within the measured concentration ranges. We performed additional experiments using the lower concentration ranges of $\mathbf{1}$. The results are shown in Figure S7. Even in the lower concentration ranges, the dosedependency was not significant. We are unable to provide a definitive reason for the observations, but we propose two possible reasons for this. First, a ligand may remain on the G4 structure that was induced by the ligand and, therefore, is not recruited for the next continuous G4 induction. Second, once G4 structures are generated, the ligands may bind nonspecifically to the G4s through other weaker binding sites or additional ligands may aggregate G4-ligand complexes; these changes would be observed as greater SPR responses at higher concentrations. These factors might suppress the ability to induce G4 formation in the presence of increased concentrations of G4s.

\section{Conclusions}

We designed and synthesized cyclic imidazole/lysine polyamide, clKP (1), as a new class of G4 ligand based on the high planarity of consecutive imidazole scaffolds, as hinted by structural studies of PIP. cIKP had high selectivity and affinity toward G4 structures over dsDNA, and modest selectivity for the particular G4 structures (24-fold). Interestingly, cIKP displayed the ability to induce G4 formation, even in the presence of the complementary strand. In recent studies, researchers have reported several new motifs that formed stable intramolecular G4s in vitro, such as motifs with bulges, long loops, and (4n-1) guanines. ${ }^{[20]}$ Considering the high affinity and induction ability of clKP toward G4, we anticipate that it might be a promising molecular probe for the detection of such new motifs or relatively unstable G4 structures that have never been discovered before in genomewide analysis.

\section{Experimental Section}

\section{General}

${ }^{1} \mathrm{H}$ NMR spectra were recorded on JEOL JNM ECA-600 spectrometer (600 $\mathrm{MHz}$ for ${ }^{1} \mathrm{H}$ and $150 \mathrm{MHz}$ for ${ }^{13} \mathrm{C}$ ), with chemical shifts reported in parts per million relative to residual solvent and coupling constants in hertz. The following abbreviations were applied to spin multiplicity: $s$ (singlet), $d$ (doublet), dd (doublet of doublets), $t$ (triplet), m (multiplet), br (broad). Regular column chromatography was performed using Silica Gel 60 (70230 mesh, Merck Chemicals). Analytical HPLC was performed on a Jasco Engineering PU-2080 plus series system using a 150 X $4.6 \mathrm{~mm}$ X-Terra MS C18 reversed-phase column in $0.1 \%$ TFA in water with acetonitrile as the eluent at a flow rate of $1.0 \mathrm{~mL} / \mathrm{min}$ and a linear gradient elution of 0 $100 \%$ acetonitrile in 20 or $40 \mathrm{~min}$ with detection at $254 \mathrm{~nm}$. Collected fractions were analyzed by ESI-TOF-MS (Bruker). Reversed-phase flash column chromatography was performed on CombiFlash Rf (Teledyne Isco, Inc.) using a $4.3 \mathrm{~g}$ reversed-phase flash column (C18 RediSep Rf) in $0.1 \%$ TFA in water with acetonitrile as the eluent at a flow rate of $18.0 \mathrm{~mL} / \mathrm{min}$ and a linear gradient elution of $0-35 \%$ acetonitrile in $5-40$ min with detection at $254 \mathrm{~nm}$. 10wt\% $\mathrm{Pd} / \mathrm{C}$ and Pentafluorophenyl diphenylphosphinate (FDPP) were purchased from Aldrich. $\mathrm{O}-(1 \mathrm{H}-6-$ chlorobenzotriazol-1-yl)-1,1,3,3-tetramethyluronium hexafluorophosphate (HCTU) were purchased from Peptide International. Diphenylphosphoryl azide (DPPA), $\mathrm{O}_{2} \mathrm{~N}-\mathrm{I}-\mathrm{COCl}_{3}$, trifluoromethansulfonic acid (TfOH), and $\mathrm{N}, \mathrm{N}-$ dimethylformamide (DMF) were purchased from Wako, and (Benzotriazol1-yloxy)tripyrrolidinophosphonium hexafluorophosphate (PyBOP) was purchased from Novabiochem. BocHN-Lys $(\mathrm{Cbz})-\mathrm{CO}_{2} \mathrm{H}$ was purchased from Watanabe Chemical Industries, LTC. Diisopropylethylamine (DIEA) was purchased from Nacalai Tesque, Inc. Trifluoroacetic acid (TFA) was purchased from Kanto Chemical Co., Inc. Dichloromethane (DCM) was purchased from Sasaki chemical co., Ltd. The other reagents and solvents were purchased from standard suppliers and used without further purification.

\section{Synthesis of cIKP (1)}

\section{Synthesis of compound 3}

To a solution of compound $2(1.01 \mathrm{~g}, 3.28 \mathrm{mmol})$, which had been synthesized in 3 steps from $\mathrm{NO}_{2}-\mathrm{I}-\mathrm{COCCl}_{3}$ in overall $83 \%$ yield, ${ }^{[21]}$ in AcOEt $(40 \mathrm{~mL})$ and $\mathrm{MeOH}(20 \mathrm{~mL})$ was added $10 \mathrm{wt} \% \mathrm{Pd} / \mathrm{C}(90 \mathrm{mg})$. The solution was stirred at rt under $\mathrm{H}_{2}$ gas atmosphere $(\mathrm{P}=0.21 \mathrm{MPa})$ for $2 \mathrm{~h}$. After the filtration of $\mathrm{Pd} / \mathrm{C}$, the filtrate was concentrated on an evaporator to give the amine compound ( $803 \mathrm{mg}, 2.88 \mathrm{mmol}$ ) as a light brown powder, which was used the next step without further purification. The amine compound (121 mg, $0.43 \mathrm{mmol}$ ), BocHN-Lys $(\mathrm{Cbz})-\mathrm{CO}_{2} \mathrm{H}(182 \mathrm{mg}, 0.49$ $\mathrm{mmol}), \mathrm{HCTU}(198 \mathrm{mg}, 0.48 \mathrm{mmol})$ was dissolved in dry DMF $(8 \mathrm{~mL})$ and to the mixture was added DIEA ( $83 \mu \mathrm{L}, 0.48 \mathrm{mmol})$. The solution was

For internal use, please do not delete. Submitted_Manuscript 
stirred at $\mathrm{rt}$ for $2.5 \mathrm{~h}$, then evaporated the solvent and washed with water to produce the oil crude, which are used in the next reaction step without further purification. For spectral data, it was purified by column chromatography (silica gel, Hexane:AcOEt 1:10) to give compound $\mathbf{3}$ as a white powder (203 mg, $73 \%$ yield). ${ }^{1} \mathrm{H}$ NMR (600 MHz, DMSO-d6) $\delta 10.32$ $(\mathrm{s}, 1 \mathrm{H}), 9.80(\mathrm{~s}, 1 \mathrm{H}), 7.70(\mathrm{~s}, 1 \mathrm{H}), 7.50(\mathrm{~s}, 1 \mathrm{H}), 7.35-7.30(\mathrm{~m}, 5 \mathrm{H}) 7.23(\mathrm{t}$, $J=5.6 \mathrm{~Hz}, 1 \mathrm{H}), 6.97(\mathrm{~d}, J=7.6 \mathrm{~Hz}, 1 \mathrm{H}), 4.99(\mathrm{~s}, 2 \mathrm{H}), 4.10(\mathrm{dd}, J=13.7$, $8.9 \mathrm{~Hz}, 1 \mathrm{H}), 3.96(\mathrm{~s}, 3 \mathrm{H}) 3.95(\mathrm{~s}, 3 \mathrm{H}), 3.82(\mathrm{~s}, 3 \mathrm{H}), 2.97(\mathrm{t}, J=17 \mathrm{~Hz}, 2 \mathrm{H})$, $1.56(\mathrm{~m}, 2 \mathrm{H}), 1.38(\mathrm{~s}, 9 \mathrm{H}), 1.31(\mathrm{~m}, 2 \mathrm{H}), 1.24(\mathrm{~m}, 2 \mathrm{H}) .{ }^{13} \mathrm{C}$ NMR (DMSOd6) $\delta 158.8,156.1,155.7,155.4,137.3,136.2,133.0,131.3,128.3,127.7$, 115.4, 114.5, 99.5, 78.0, 65.1, 59.7, 54.2, 51.8, 35.6, 35.0, 31.5, 29.1, 28.2, 22.8. ESI-MS m/z calcd for $\mathrm{C}_{30} \mathrm{H}_{40} \mathrm{~N}_{8} \mathrm{O}_{8}[\mathrm{M}+\mathrm{H}] 641.3042$, found 641.3112 .

\section{Synthesis of compound 5}

To a solution of compound 3 (203 $\mathrm{mg}, 0.32 \mathrm{mmol})$ in $\mathrm{MeOH}(6 \mathrm{~mL})$ and $\mathrm{H}_{2} \mathrm{O}(6 \mathrm{~mL})$ was added a solid $\mathrm{NaOH}(460 \mathrm{mg})$, then the mixture was heated at $45^{\circ} \mathrm{C}$ for $1 \mathrm{~h}$. After the evaporation of $\mathrm{MeOH}$, the resulting solution was acidized with $6 \mathrm{~N} \mathrm{HCl}$ aq to produce a white precipitation. It was collected by filtration and dried in vacuo to give the carboxylic acid $(159 \mathrm{mg})$ as a white powder, which was used the next step without further purification. To a solution of the carboxylic acid $(32.6 \mathrm{mg})$ in DCM $(1.5 \mathrm{~mL})$ was added TFA $(1.5 \mathrm{~mL})$. The solution was stirred at it for $1 \mathrm{~h}$, then evaporated the solvent and dried in vacuo to give the TFA salt of compound $\mathbf{4}$ as a light brown solid, which was used the next step without further purification. The salt of compound 4 and FDPP $(79 \mathrm{mg}, 0.21 \mathrm{mmol})$ was dissolved in dry DMF $(8.7 \mathrm{~mL})$ and to the mixture was added DIEA $(54 \mu \mathrm{L}, 0.31 \mathrm{mmol})$. The solution was stirred at it for $4 \mathrm{~h}$, then evaporated the solvent. The crude was dissolved in a minimum amount of DCM and recrystallized with $\mathrm{Et}_{2} \mathrm{O}$ to give compound 7 as a white powder $(27.4 \mathrm{mg}$, $52 \%$ for 3 steps). Three ordinary condensation agents, PyBOP, HCTU, and DPPA, were also used for this dimerization reaction with comparable yield $\left(40 \%, 36 \%\right.$, and $32 \%$, respectively). ${ }^{1} \mathrm{H}$ NMR $\left(600 \mathrm{MHz}\right.$, DMSO- $\left.d_{6}\right) \delta$ $10.19(\mathrm{~s}, 2 \mathrm{H}), 9.41(\mathrm{~s}, 2 \mathrm{H}), 8.82(\mathrm{~d}, J=9.7 \mathrm{~Hz}, 2 \mathrm{H}), 7.52(\mathrm{~s}, 2 \mathrm{H}), 7.46$ (s, 2H) 7.36-7.29 (m, 10H), $7.25(\mathrm{t}, J=5.7 \mathrm{~Hz}, 2 \mathrm{H}), 4.99(\mathrm{~s}, 4 \mathrm{H}), 4.59(\mathrm{dd}, J$ $=15.8,9.6 \mathrm{~Hz}, 2 \mathrm{H}), 4.00(\mathrm{~s}, 6 \mathrm{H}) 3.94(\mathrm{~s}, 6 \mathrm{H}), 2.99(\mathrm{t}, J=13.1 \mathrm{~Hz}, 4 \mathrm{H})$, $1.85(\mathrm{~m}, 2 \mathrm{H}), 1.75(\mathrm{~m}, 2 \mathrm{H}), 1.49-1.42(\mathrm{~m}, 4 \mathrm{H}), 1.38-1.31(\mathrm{~m}, 4 \mathrm{H}) .{ }^{13} \mathrm{C} \mathrm{NMR}$ (DMSO-d ) $168.8,157.9,156.1,154.8,137.3,135.6,134.7,134.3,133.2$ 128.3, 127.7, 114.9, 113.0, 65.1, 53.7, 34.9, 32.2, 28.9, 22.8. ESI-MS m/z calcd for $\mathrm{C}_{48} \mathrm{H}_{56} \mathrm{~N}_{16} \mathrm{O}_{16}[\mathrm{M}+\mathrm{H}]^{+}$1017.4438, found 1017.4467.

\section{Synthesis of compound 1}

To a solution of compound 5 (11.6 mg, $11.4 \mu \mathrm{mol})$ in TFA $(800 \mu \mathrm{L})$ was slowly added TfOH $(80 \mu \mathrm{L})$. The solution was stirred at it for $5 \mathrm{~min}$, then poured into cold $\mathrm{Et}_{2} \mathrm{O}(5 \mathrm{~mL})$ to produce a light brown precipitate, which was collected by a centrifuge. The pellet was purified by reverse-phase flash chromatography to give compound $\mathbf{1}$ as a white powder $(10.9 \mathrm{mg}$, $98 \%$ yield). ${ }^{1} \mathrm{H}$ NMR $\left(600 \mathrm{MHz}, \mathrm{DMSO}-\mathrm{d}_{6}\right) \delta 10.27$ (s, 2H), 9.42 (s, 2H), $8.86(\mathrm{~d}, J=9.6 \mathrm{~Hz}, 2 \mathrm{H}), 7.72(\mathrm{br} \mathrm{s}, 4 \mathrm{H}), 7.53(\mathrm{~s}, 2 \mathrm{H}) 7.46(\mathrm{~s}, 2 \mathrm{H}), 4.61(\mathrm{dd}$ $J=15.8,9.6 \mathrm{~Hz}, 2 \mathrm{H}), 4.01(\mathrm{~s}, 6 \mathrm{H}) 3.95(\mathrm{~s}, 6 \mathrm{H}), 2.80(\mathrm{t}, J=13.1 \mathrm{~Hz}, 4 \mathrm{H})$, $1.87(\mathrm{~m}, 2 \mathrm{H}), 1.76(\mathrm{~m}, 2 \mathrm{H}), 1.64-1.55(\mathrm{~m}, 4 \mathrm{H}), 1.45-1.35(\mathrm{~m}, 4 \mathrm{H}) .{ }^{13} \mathrm{C}$ NMR $\left(\right.$ DMSO- $\left.d_{6}\right) \delta 169.3,158.5,155.3,136.1,135.2,134.8,133.7,115.5,113.6$ 54.0, 39.2, 35.4, 32.6, 27.1, 23.0. ESI-MS m/z calcd for $\mathrm{C}_{32} \mathrm{H}_{44} \mathrm{~N}_{16} \mathrm{O}_{6}$ $[\mathrm{M}+\mathrm{H}]^{+}$749.3702, found 749.3704 .

\section{SPR-binding experiments}

SPR experiments were performed on a Biacore $X$ instrument (GE healthcare) acording to previous reports with some modifications. $5^{\prime}$ Biotinylated DNAs were purchased from JbioS (Table S1). The biotinylated DNAs were immobilized to streptavidin-functionalized SA sensor chips to obtain the desired immobilization level. SPR measurements were carried out using degassed and filtered HBS buffer (10 mM HPES pH 7.4, $150 \mathrm{mM}$ $\mathrm{NaCl}, 3 \mathrm{mM}$ EDTA, and $0.005 \%$ Surfactant P20) with $0.1 \%$ DMSO and 100 $\mathrm{mM} \mathrm{KCl}$ at $25^{\circ} \mathrm{C}$. A series of sample solutions with a wide range of concentrations were prepared in the buffer with $0.1 \%$ DMSO and $100 \mathrm{mM}$ $\mathrm{KCl}$, and injected at a flow rate of $20 \mu \mathrm{l} / \mathrm{min}$. After each cycle, the samples remainig on the DNA was detatched with $50 \mathrm{mM} \mathrm{NaOH} / 1 \mathrm{M} \mathrm{NaCl}$ buffer until the baseline of the sensorgrams was recovered. Optimized concentration range was then selected for the subsequent quantitative anlalysis. The resulting sensorgrams were fitted with 1:1 (single site) or modified heterogenous ligand (two site) binding model with mass tranfer using BIAevaluation 4.1 program in order to obtain the values of kinetics parameters $\left(k_{\mathrm{a}}\right.$ and $\left.k_{\mathrm{d}}\right)$ and binding affinites $\left(K_{\mathrm{D}}\right)$. These two fitting models include equations that reflect mass transfer limitation effect. The best fitted curves were shown in Figure 2.

\section{CD spactra measurements}

DNA samples for CD spectra were prepared in $10 \mathrm{mM}$ Tris- $\mathrm{HCl}(\mathrm{pH} 7.5)$ buffer. Annealing was performed by heating to $95{ }^{\circ} \mathrm{C}$ for $5 \mathrm{~min}$ and gradually cooling down to room temperature in the presence or absence of 1. For CD titration assays, to the solution of the annealed DNA $(5 \mu \mathrm{M})$ in the buffer was added various concentrations of $\mathbf{1}$, the solution was incubated for $30 \mathrm{~min}$. CD spectra were measured in $0.5-\mathrm{nm}$ steps from 340 to $220 \mathrm{~nm}$ using JASCO J-805LST Spectrometer in a $1-\mathrm{cm}$ quartz cuvette, and shown in Figure S2 and S3.

\section{Native gel electrophoresis analysis}

DNA samples for gel electrophoresis were prepared in $10 \mathrm{mM}$ Tris- $\mathrm{HCl}$ (pH 7.5) buffer containing $40 \%$ (w/v) PEG 200 with or without $50 \mathrm{mM} \mathrm{KCl}$. The DNA samples was heated to $95^{\circ} \mathrm{C}$ for 5 min and gradually cooled down to room temperature. 1 was added to the resulting DNA solution (200 $\mathrm{nM}$ ) and incubated for $30 \mathrm{~min}$ at $37^{\circ} \mathrm{C}$. Those samples were loaded on $12 \%$ polyacrylamide gel containing $50 \mathrm{mM} \mathrm{KCl}$, and electrophoresed at $4{ }^{\circ} \mathrm{C}, 100 \mathrm{~V}$, in $1 \times$ TBE buffer containing $50 \mathrm{mM} \mathrm{KCl}$ for $90 \mathrm{~min}$. The gel was stained with SYBR gold for $15 \mathrm{~min}$ and then imaged by FUJIFILM FLA-3000 (FUJIFILM).

\section{Acknowledgements}

This work was partially supported by JSPS KAKENHI (grant number 24225005 to H. S and 24310155 to T. B.).

Keywords: cyclic polyamide • G-quadruplexes • G4 induction • heterocycles $\cdot$ molecular crowding condition

[1] a) M. Gellert, M. N. Lipsett, D. R. Davies, Proc .Nat.I Acad. Sci. U. S. A 1962, 48, 2013-2018. b) D. Sen, W. Gilbert, Nature 1988, 334, 364-366. c) M. W. da silva, Chem. Eur.-J. 2007, 13, 9738-9745. d) Sannohe, Y.; Sugiyama, H. Curr. Protoc. Nucleic Acid Chem. 2010, 17.2, 1-17. e) D. J. Patel, A. T. Phan, V. Kuryavyi, Nucleic Acids Res. 2007, 35, 74297455

[2] a) J. L. Huppert, S. Balasubramanian, Nucleic Acids Res. 2005, 33 2908-2916. b) J. L. Huppert, S. Balasubramanian, Nucleic Acids Res., 2007, 35, 406-413. c) A. M. Zahler, J. R. Williamson, T. R. Cech, D. M. Prescott, Nature 1991, 350, 718-720. d) E. Y. N. Lam, D. Beraldi, D. Tannahill, S. Balasubramanian, Nat. Commun. 2013, 4, 1796-1811. e) S. Muller, S. Kumari, R. Rodriguez, S. Balasubramanian, Nat. Chem 2010, 2, 1095-1098.

[3] a) R. Rodriguez, K. M. Miller, J. V. Forment, C. R. Bradshaw, M. Nikan, S. Britton, T. Oelschlaegel, B. Xhemalce, S. Balasubramanian, S. P. 
Jackson, Nat. Chem. Biol. 2012, 8, 301-310. b) C. L. Grand, H. Han, R. M. Muñoz, S. Weitman, D. D. Von Hoff, L. H. Hurley, D. J. Bearss, Mol. Cancer Ther. 2002, 1, 565-573. c) M .J. Law, K. M. Lower, H. P. Voon, J. R. Hughes, D. Garrick, V. Viprakasit, M. Mitson, M. De Gobbi, M. Marra A. Morris, A. Abbott, S. P. Wilder, S. Taylor, G.M. Santos, J. Cross, H. Ayyub, S. Jones, J. Ragoussis, D. Rhodes, I. Dunham, D. R. Higgs, R. J. Gibbons, Cell 2010, 143, 367-378. d) M.-Y. Kim, H. Vankayalapati, K. Shin-ya, K. Wierzba, L. H. Hurley J. Am. Chem. Soc. 2002, 124, 20982099. e) Y. Qin, L. H. Hurley, Biochemie 2008, 90, 1149-1171. f) T. A. Brooks, L. H. Hurley, Genes \& Cancer 2010, 1, 641-649. g) S. Balasubramanian, L. H. Hurley, S. Neidle, Nat. Rev. Drug Discovery 2011, 10, 261-175.

[4] a) D. Monchaud, M.-P. Teulade-Fichou, Org. Biomol. Chem., 2008, 6, 627-636. b) N. W. Luedtke, Chimia 2009, 63, 134-139.

[5] a) K. Shin-ya, K. Wierzba, K.-I. Matsuo, T. Ohtani, Y. Yamada, K. Furihata, Y. Hayakawa, H. Seto, J. Am. Chem. Soc. 2001, 123, 12621263. b) T. Doi, M. Yoshida, K. Shin-ya, T. Takahashi, Org. Lett. 2006, 8, 4165-4167.

[6] T. Agarwal, S. Roy, T. K. Chakraborty, S. Maiti, Biochemistry 2010, 49, 8388-8397.

[7] M. Tera, H. Ishizuka, M. Takagi, M. Suganuma, K. Shin-ya, K. Nagasawa Angew. Chem. Int. Ed. 2008, 47, 5557-5560.

[8] a) D. P. N. Goncalves, R. Rodriguez, S. Balasubramanian, J. K. M. Sanders, Chem. Commun. 2006, 45, 4685-4687. b) P. S. Shirude, E. R. Gillies, S. Ladame, F. Godde, K. Shin-ya, I. Huc, S. Balasubramanian, J. Am. Chem. Soc. 2007, 129, 11890-11891. c) K. Shinohara, Y. Sannohe, S. Kaieda, K. Tanaka, H. Osuga, Y. Xu, T. Bando, H. Sugiyama, J. Am. Chem Soc. 2010, 132, 3778-3782. d) K. Jantos, R. Rodriguez, S. Ladame, P. S. Shirude and S. Balasubramanian, J. Am. Chem. Soc. 2006, 128, 13662-13663. e) Q. Zhang, X. Cui, S. Lin, J. Zhou, G. Yuan, Org. Lett. 2012, 14, 6126-6129. f) J. M. Nicoludis, S. P. Barrett, J. L. Mergny, L.A. Yatsunyk, Nucleic Acids Res., 2012, 40, 5432-5447. g) D. M. Kong, Y. E. Ma, , J. H. Guo, W. Yang, H. X. Shen, Anal. Chem., 2009 81, 2678-2684. h) A. Arora, S. Maiti, J. Phys. Chem. B 2008, 112, 81518159. i) G. S. Minhas, D. S. Pilch, J. E. Kerrigan, E. J. LaVoie, J. E. Rice, Bioorg. Med. Chem. Lett., 2006, 16, 3891-3895.

[9] P. B. Dervan, B. S. Edelson, Curr. Opin. Struct. Biol. 2003, 13, 284-299.

[10] Y.-W. Han, T. Matsumoto, H. Yokota, G. Kashiwazaki, H. Morinaga, K. Hashiya, T. Bando, Y. Harada, H. Sugiyama, Nucleic Acids Res. 2012, 40. 11510-11517.
[11] M. J. Cocco, L. A. Hanakahil, M. D. Huber, N. Maizels, Nucleic Acids Res., 2003, 31, 2944-2951.

[12] W. J. Chung, B. Heddi, M. Tera, K. lida, K. Nagasawa, A. T. Phan, J. Am. Chem. Soc. 2013, 135, 13495-13501.

[13] a) E. R. Lacy, N. M. Le, C. A. Price, M. Lee, M. W. D. Wilson, J .Am. Chem. Soc. 2002, 124, 2153-2163. b) S. Asamitsu, S. Y. Kawamoto, F. Hashiya, K. Hashiya, M. Yamamoto, S. Kizaki, T. Bando, H. Sugiyama, Bioorg. Med. Chem., 2014, 22, 4646-4657.

[14] a) J. Seenisamy, S. Bashyam, V. Gokhale, H. Vankayalapati, D. Sun, A. Siddiqui-Jain, N. Streiner, K. Shin-ya, E. White, W. D. Wilson, L. H. Hurley, J. Am. Chem. Soc. 2005, 127, 2944-2959. b) E. M. Rezler, J. Seenisamy, S. Bashyam, M.-Y. Kim, E. White, W. D. Wilson, L. H. Hurley, J. Am. Chem. Soc. 2005, 127, 9439-9447. c) Bejugam, S. Sewitz, P. S. Shirude, R. Rodriguez, R. Shahid, S. Balasubramanian, J. Am. Chem. Soc. 2007, 129, 12926-12927. d) X.-D. Wang, T.-M. Ou, Y.-J. Lu, Z. Li, Z. Xu, C. Xi, J.-H. Tan, S.-L. Huang, L.-K. An, D. Li, L.-Q. Gu, Z.-S. Huang, J. Med. Chem. 2010, 53, 4390-4398.

[15] R. Rodriguez, G. D. Pantos, D. P. N. Goncalves, J. K. M. Sanders, S. Balasubramanian, Angew. Chem. Int. Ed. 2007, 46, 5405-5407.

[16] A. I. Karsisiotis, N. M. Hessari, E. Novellino, G. P. Spada, A. Randazzo, M. W. da Silva, Angew. Chem. Int. Ed. 2011, 50, 10645-10648.

[17] A. Rangan, O. Y. Fedoroff, L. H. Hurley, J. Biol. Chem. 2001, 276, 46404646

[18] a) K. Zheng, Z. Chen, Y. Hao, Z. Tan, Nucleic Acids Res. 2010, 38, $327-$ 338. b) C. Zhang, H. Liu, K. Zheng, Y. Hao, Zheng Tan, Nucleic Acids Res. 2013, 41, 7144-7152.

[19] a) S. Rankin, A. P. Reszka, J. Huppert, M. Zloh, G. N. Parkinson, A. K. Todd, S. Ladame, S. Balasubramanian, S. Neidle, J. Am. Chem. Soc 2005, 127, 10584-10589. b) A. T. Phan, V. Kuryavyi, S. Burge, S. Neidle D. J. Patel, J. Am. Chem. Soc. 2007, 129, 4386-4392. c) T. S Dexheimer, D. Sun, L. H. Hurley, J. Am. Chem. Soc. 2006, 128, 5404-5415

[20] a) V. S. Chambers, G. Marsico, J. M. Boutell, M. D. Antonio, G. P. Smith S. Balasubramanian Nat. Biotechnol., 2015, 33, 877-881. b) V. T. Mukundan, A. T. Phan, J. Am. Chem. Soc., 2013, 135, 5017-5028. c) B. Heddi, N. Martìn-Pintado, Z. Serimbetov, T. M. A. Kari, A. T. Phan, Nucleic Acids Res. 2016, 44, 910-916.

[21] J. Xiao, G. Yuan, W. Huang, J. Org. Chem. 2000, 65, 5506-5513. 
Entry for the Table of Contents (Please choose one layout)

Layout 2:

\section{FULL PAPER}

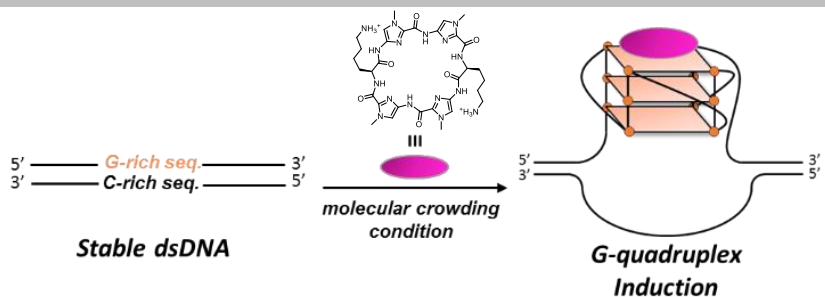

G-quadruplex inducer: cyclic imidazole/lysine polyamide (cIKP) as a new class of G-quadruplex ligand was designed and synthesized. It exhibited the ability to induce G4 formation, even in the presence of the complementary strand. It may be applicable as a molecular probe for the detection of potential novel G4s.
S. Asamitsu, Y. Li, T. Bando*, H. Sugiyama*

Page No. - Page No.

Ligand-mediated G-quadruplex Induction in a Double-stranded DNA Context by Cyclic Imidazole/Lysine Polyamide 


\section{Supporting Information}

Ligand-mediated G-quadruplex Induction in a Double-stranded DNA Context by Cyclic Imidazole/Lysine Polyamide

Sefan Asamitsu, Yue Li, Toshikazu Bando*, and Hiroshi Sugiyama * 


\section{Table of contents}

\section{Spectrum data of compound 3,5 and 1 (S3-S5)}

\section{Supplemental Data (S6-S11)}

Table S1. DNA oligomers used in this study.

Table S2. Values of the kinetic parameters and dissociate constants for the weaker binding sites (Telomere, $c$-kit 1, c-kit 2, and BCL2 G4s).

Figure S1. SPR sensorgrams for duplex DNAs (GC-rich and AT-rich).

Figure S2. CD spectra of $c-M y c, c$-kit 1, $c$-kit 2, and BCL2 ssDNA after the addition of 1.

Figure S3. CD spectra of $c-M y c, c$-kit 1, c-kit 2, and BCL2 ssDNA in the presence of $\mathbf{1}$ under no $\mathrm{K}^{+}$.

Figure S4. Native gel images of $c$-Myc, c-kit 1, c-kit 2, and BCL2 dsDNA after incubation with TMPyP4 under PEG condition.

Figure S5. Native gel images of $c$-Myc, c-kit 1, c-kit 2, and BCL2 dsDNA after incubation of $\mathbf{1}$ under no PEG condition.

Figure S6. Native gel images of $c-M y c$ dsDNA after incubation of $\mathbf{1}$ in the absence of $\mathrm{K}^{+}$under PEG condition.

Figure S7. Native gel images of $c-M y c$ dsDNA after incubation of $\mathbf{1}$ at the lower concentration ranges in the absence of $\mathrm{K}^{+}$under PEG condition. 


\section{Spectral data}

\section{${ }^{1} \mathrm{H}$ NMR and ${ }^{13} \mathrm{C}$ NMR spectra of compound 3}

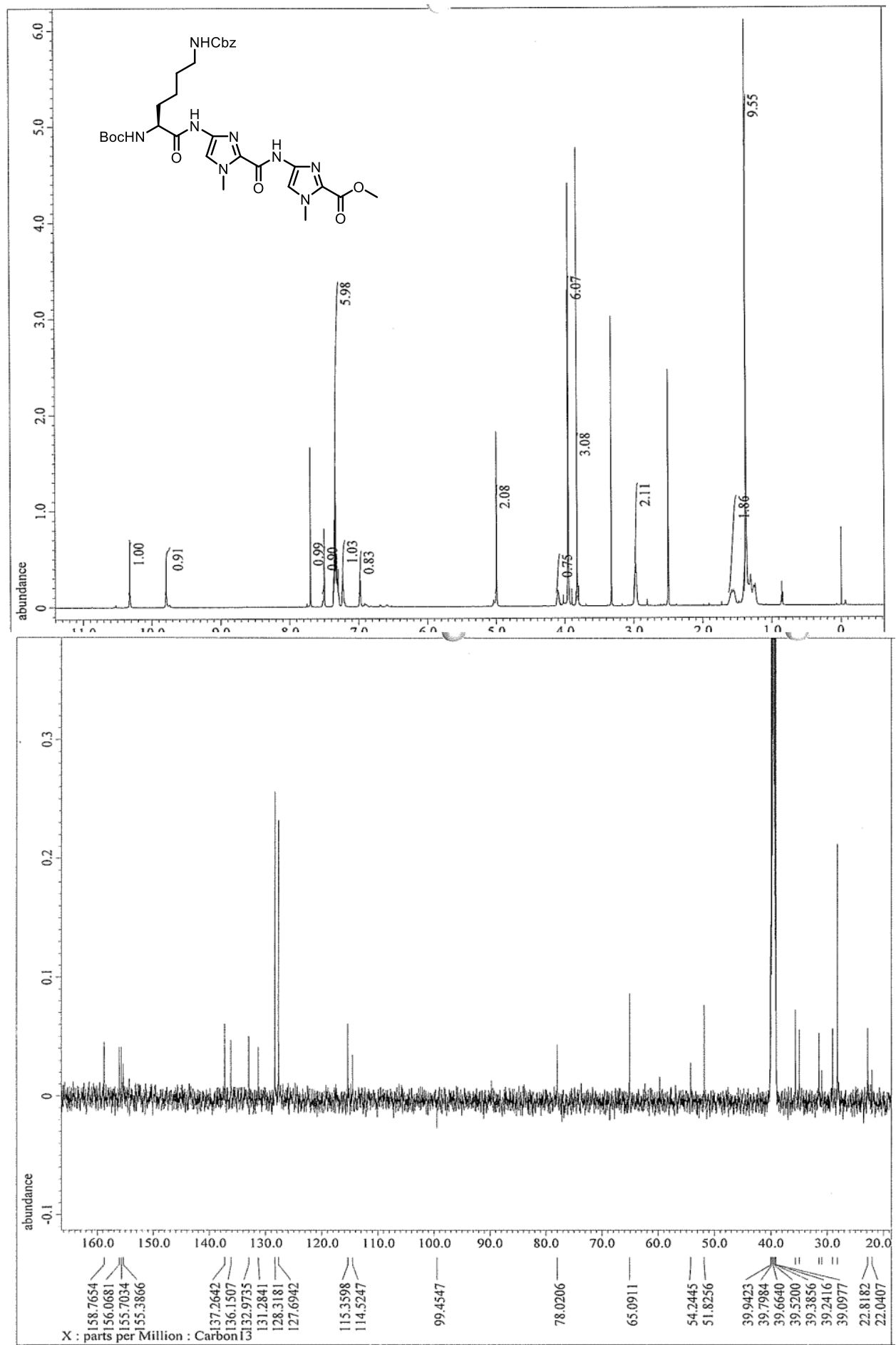




\section{${ }^{1} \mathrm{H}$ NMR and ${ }^{13} \mathrm{C}$ NMR spectra of compound 5}
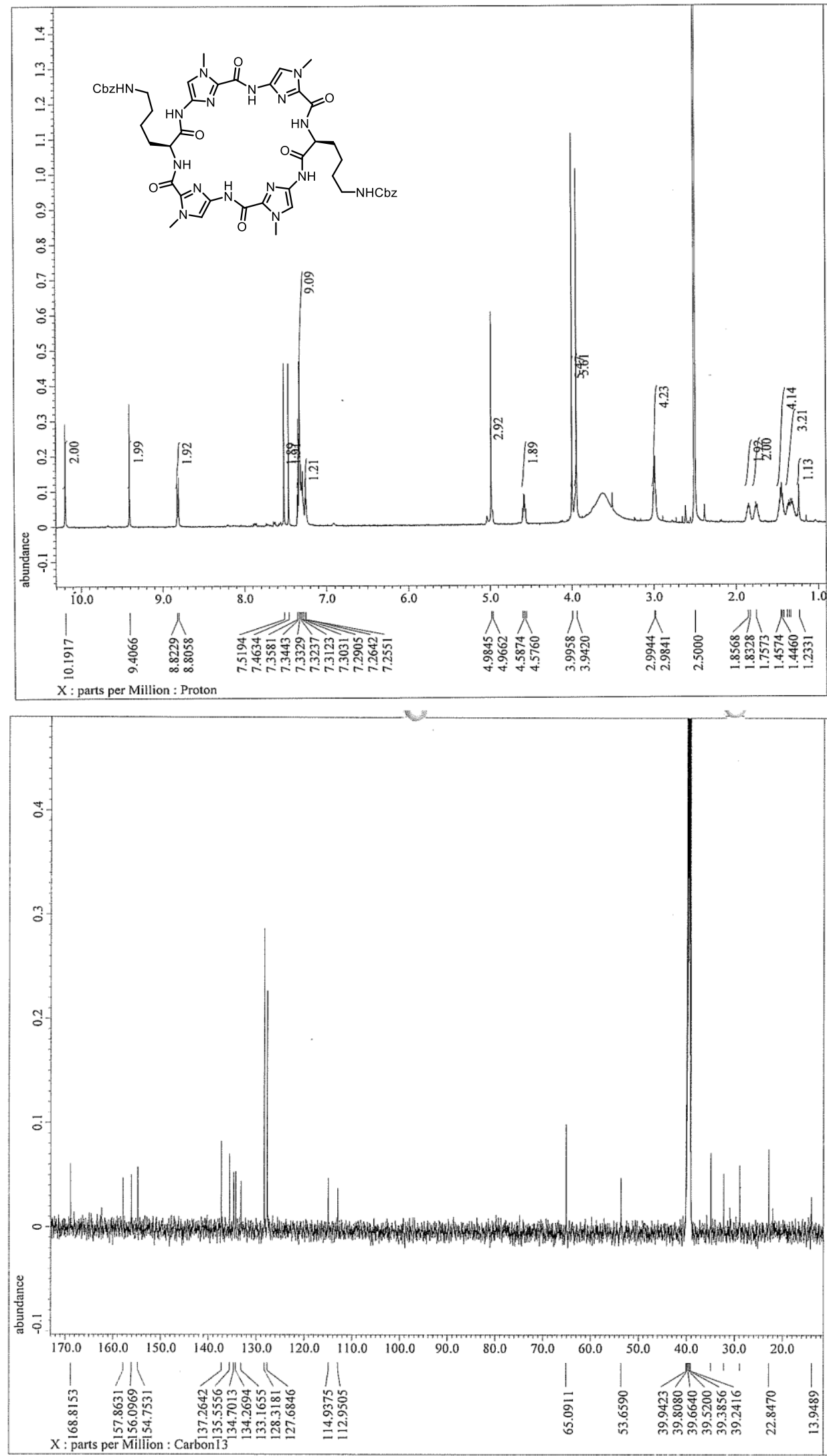


\section{${ }^{1} \mathrm{H}$ NMR and ${ }^{13} \mathrm{C}$ NMR spectra of compound 1}
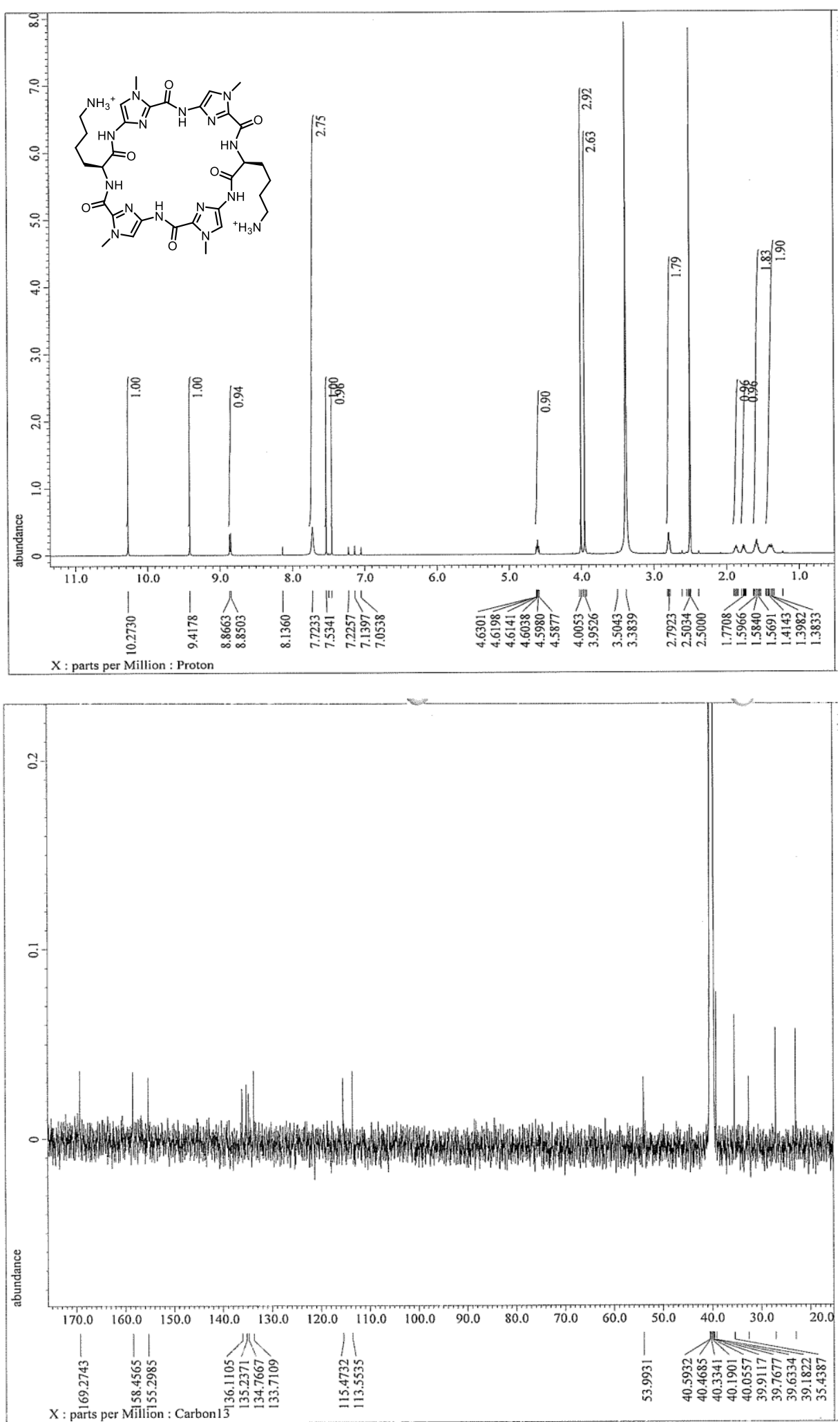


\section{Supplemental data}

Table S1. DNA oligomers used in this study.

\begin{tabular}{|c|c|}
\hline DNA & Sequence $\left(5^{\prime}-3^{\prime}\right)$ \\
\hline telomere & biotin-TTTAGGGTTAGGGTTAGGGTTAGGG \\
\hline$c-M y c$ & biotin-TTTTGGGGAGGGTGGGGAGGGTGGGGAAGG \\
\hline c-kit 1 & biotin-TTTAGGGAGGGCGCTGGGAGGAGGG \\
\hline c-kit 2 & biotin-TTTCGGGCGGGCGCGAGGGAGGGG \\
\hline$B C L 2$ & biotin-TTTGGGCGCGGGAGGAAGGGGGCGGG \\
\hline GC-rich dsDNA & biotin-GCCGCGCGCGCTTATTTTAAGCGCGCGCGGC \\
\hline AT-rich dsDNA & biotin-GCCATATATATTTATTTTTAAATATATATGGC \\
\hline$c-M y c$ ssDNA & TGGGGAGGGTGGGGAGGGTGGGGAAGG \\
\hline c-kit 1 ssDNA & AGGGAGGGCGCTGGGAGGAGGG \\
\hline$c$-kit 2 ssDNA & CGGGCGGGCGCGAGGGAGGGT \\
\hline$B C L 2$ ssDNA & GGGCGCGGGAGGAATTGGGCGGG \\
\hline \multirow{3}{*}{$c-M y c$ dsDNA } & GCGGTTCTGAACTCGATAT GGGTGGGTAGGGTGGG ATTAGTGCTAGCTACGCG \\
\hline & CGCGTAGCTAGCACTAAT CCCACCCTACCCACCC ATATCGAGTTCAGAACCGC \\
\hline & CGCGTAGCTAGCACTAAT TTTTTTTTTTTTTTT ATATCGAgTTCAGAACCGC \\
\hline \multirow{3}{*}{$c$-kit $1 \mathrm{dsDNA}$} & GCGGTTCTGAACTCGATAT AGGGAGGGCGCTGGGAGGAGGG ATTAGTGCTAGCTACGCG \\
\hline & CGCGTAGCTAGCACTAAT CCCTCCTCCCAGCGCCCTCCCT ATATCGAGTTCAGAACCGC \\
\hline & CGCGTAGCTAGCACTAAT TTTTTTTTTTTTTTTTTTTTT ATATCGAGTTCAGAACCGC \\
\hline \multirow{3}{*}{ c-kit 2 dsDNA } & GCGGTTCTGAACTCGATAT CGGGCGGGCGCGAGGGAGGGG ATTAGTGCTAGCTACGCG \\
\hline & CGCGTAGCTAGCACTAAT CCCCTCCCTCGCGCCCGCCCG ATATCGAGTTCAGAACCGC \\
\hline & CGCGTAGCTAGCACTAAT TTTTTTTTTTTTTTTTTTTTT ATATCGAGTTCAGAACCGC \\
\hline \multirow{3}{*}{$B C L 2$ dsDNA } & GCGGTTCTGAACTCGATAT GGGCGCGGGAGGAAGGGGGCGGG ATTAGTGCTAGCTACGCG \\
\hline & CGCGTAGCTAGCACTAAT CCCGCCCCCTTCCTCCCGCGCCC ATATCGAGTTCAGAACCGC \\
\hline & CGCGTAGCTAGCACTAAT TTTTTTTTTTTTTTтTTTTTTT ATATCGAGTTCAGAACCGC \\
\hline
\end{tabular}


Table S2. Values of the association rates $\left(k_{\mathrm{a}}\right)$ and dissociation rates $\left(k_{\mathrm{d}}\right)$ obtained from curve fittings of the sensorgrams, and dissociation constants $\left(K_{\mathrm{D}}\right)$ for the weaker binding sites.

\begin{tabular}{cccc}
\hline & \multicolumn{3}{c}{$\operatorname{cIKP}(\mathbf{1})$} \\
\cline { 2 - 4 } DNA & $k_{\mathrm{a}}\left[\mathrm{M}^{-1} \mathrm{~s}^{-1}\right]$ & $k_{\mathrm{d}}\left[\mathrm{s}^{-1}\right]$ & $K_{\mathrm{D}}[\mathrm{nM}]$ \\
\hline Telomere $^{[\mathrm{a}]}$ & $1.7 \times 10^{4}$ & $2.3 \times 10^{-3}$ & 131 \\
$c-k i t-1^{[\mathrm{a}]}$ & $3.7 \times 10^{4}$ & $9.8 \times 10^{-3}$ & 262 \\
$c-k i t-2^{[\mathrm{a}]}$ & $3.8 \times 10^{4}$ & $1.1 \times 10^{-2}$ & 291 \\
$B C L 2^{[\mathrm{a}]}$ & $4.4 \times 10^{4}$ & $2.4 \times 10^{-3}$ & 53 \\
\hline
\end{tabular}

[a] Determined by fitting with a modified heterogeneous ligand-binding model (two-site binding model).

(a)

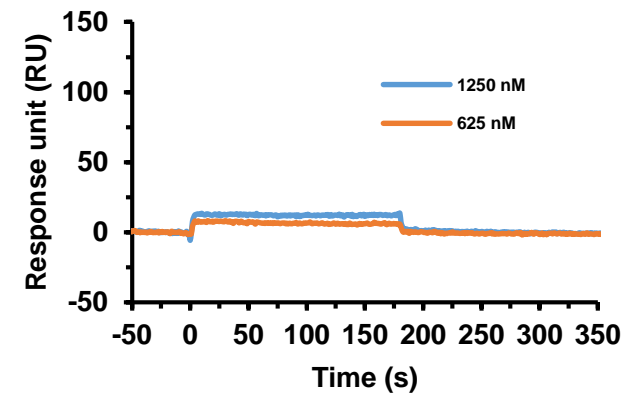

(b)

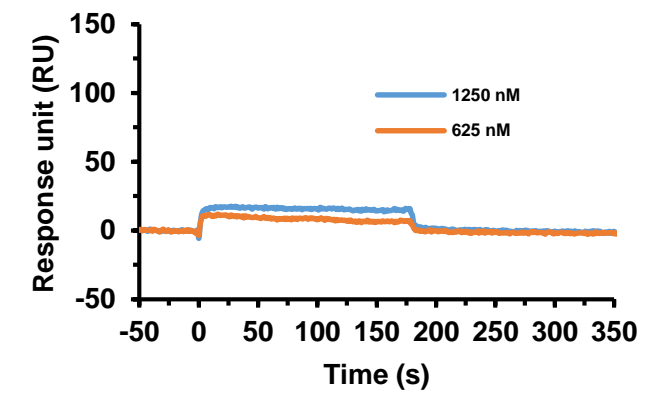

Figure S1. SPR-binding assays to evaluate the binding properties of cIKP (1). (a,b) SPR sensorgrams for interactions with duplex DNA including GC- or AT-rich sequences, respectively. 
(a)

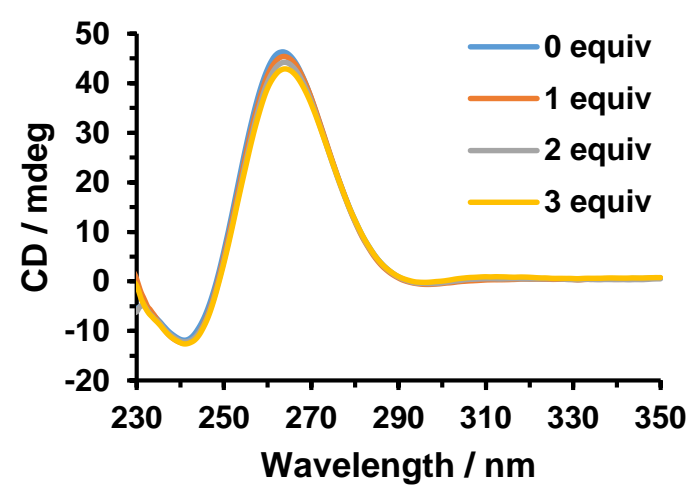

(c)

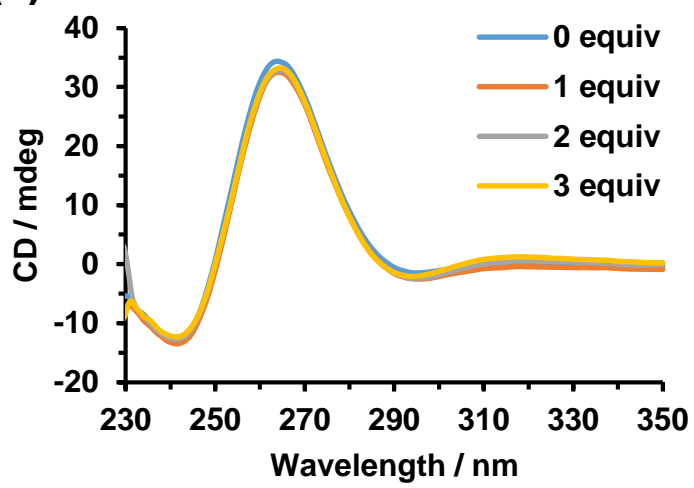

(b)

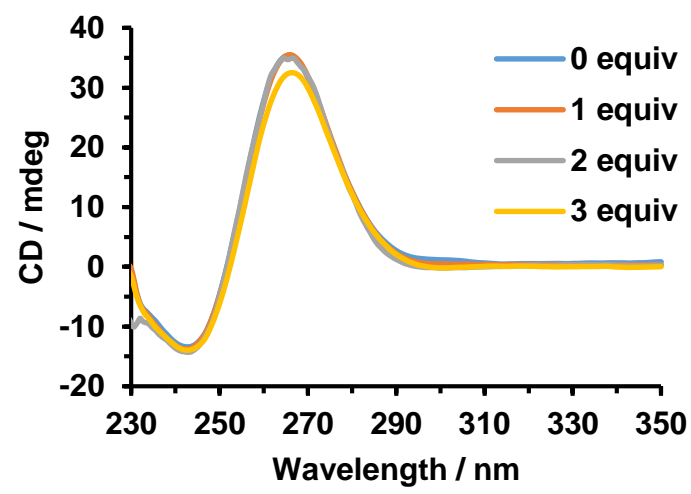

(d)

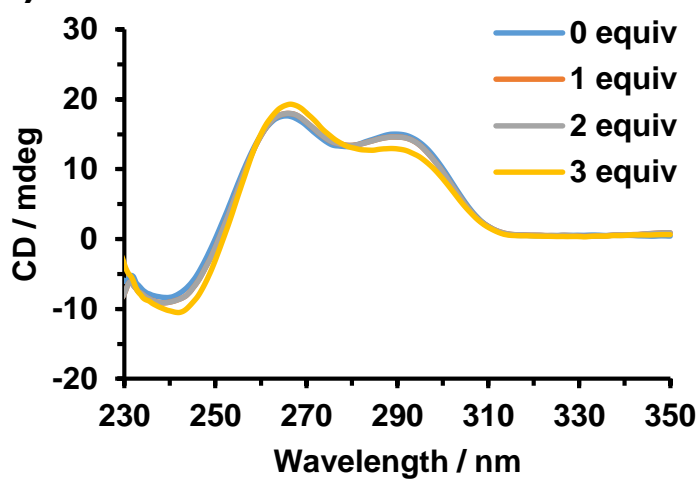

Figure S2. CD spectra of $c$-Myc (a), c-kit 1 (b), c-kit 2 (c), and BCL2 (d) ssDNA (5 $\mu \mathrm{M})$ after the addition of $\mathbf{1}$ ( 5 to $15 \mu \mathrm{M}$ ) under $50 \mathrm{mM} \mathrm{K}^{+}$solution. A moderate positive peak at $262 \mathrm{~nm}$ and a negative peak at $240 \mathrm{~nm}$ is characteristic of parallel conformations (a,b,c), and A positive peak around at 264 and $290 \mathrm{~nm}$ and a negative peak around at $240 \mathrm{~nm}$ is characteristic of mixed parallel/antiparallel conformations (d). 
(a)

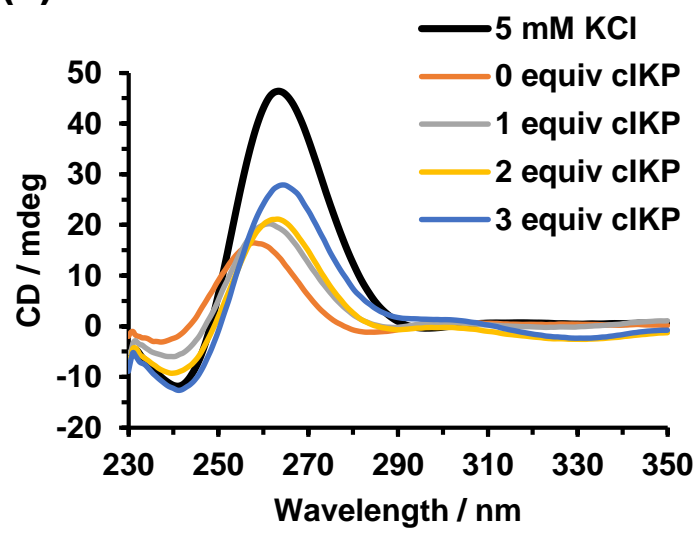

(c)

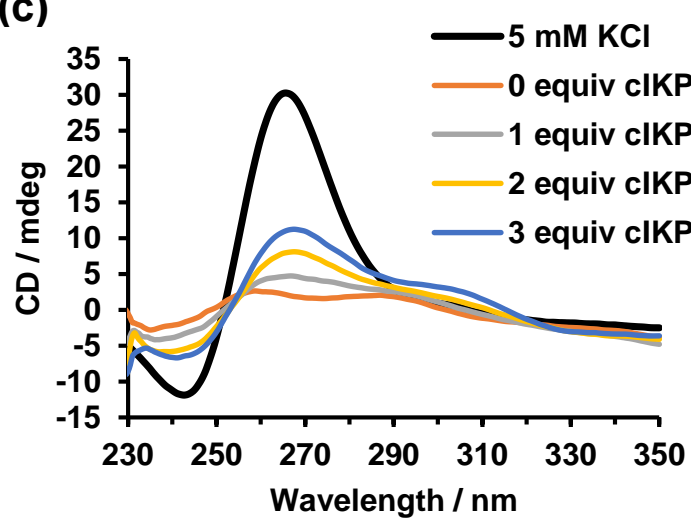

(b)

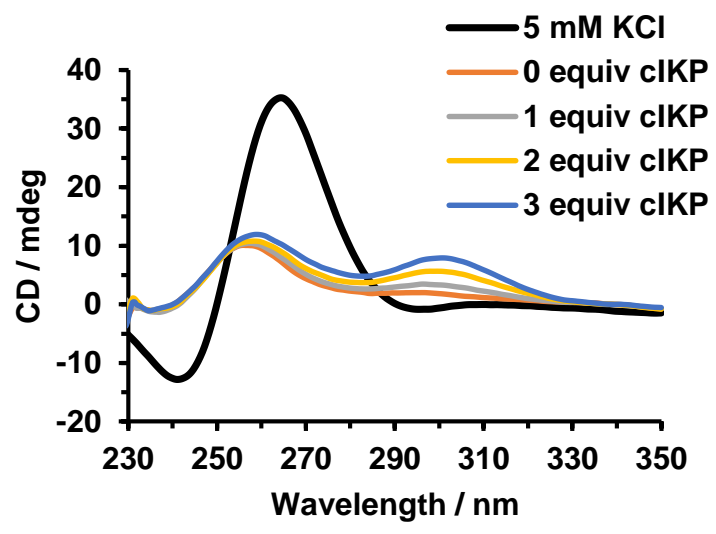

(d)

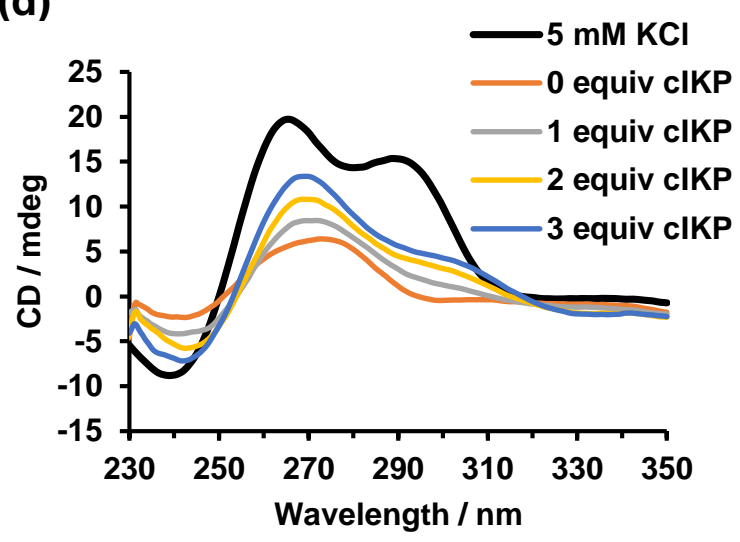

Figure S3. CD spectra of $c-M y c$ (a), c-kit 1 (b), c-kit 2 (c), and BCL2 (d) ssDNA (5 $\mu \mathrm{M})$ in the presence of $\mathbf{1}(5$ to $15 \mu \mathrm{M})$ under no $\mathrm{K}^{+}$. 
(a)

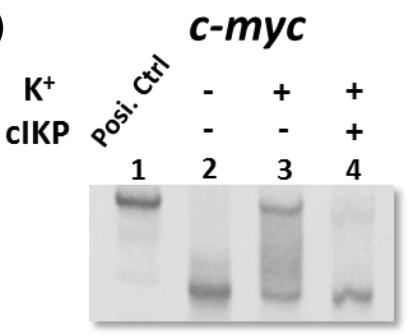

(c)

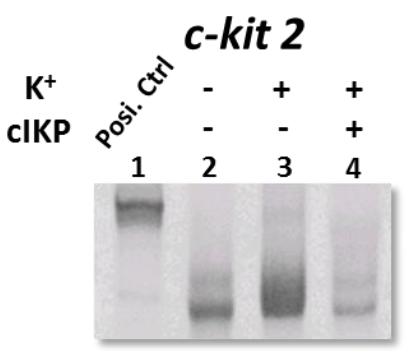

(b)

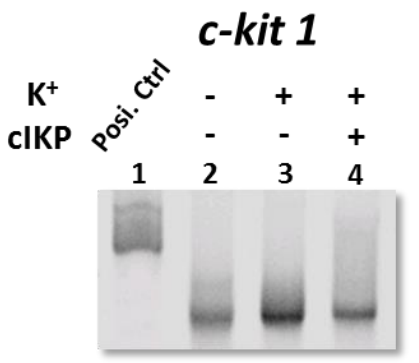

(d)

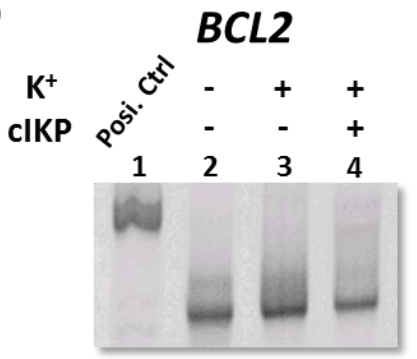

Figure S4. No induction of G4 formation by TMPyP4 (Figure 1b) by native gel electrophoresis under PEG solution; (a) c-Myc dsDNA, (b) c-kit 1 dsDNA, (c) c-kit 2 dsDNA, (d) BCL2 dsDNA. Lane 1 is a positive control (Posi. Ctrl) for G4 formation bands. Lane 2 shows dsDNA bands as negative controls.

(a)

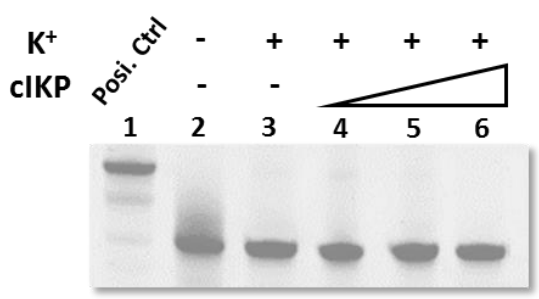

(b)
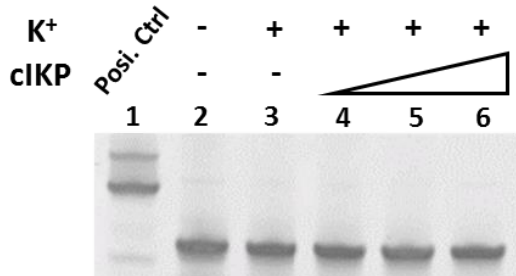

(c) c-kit 2

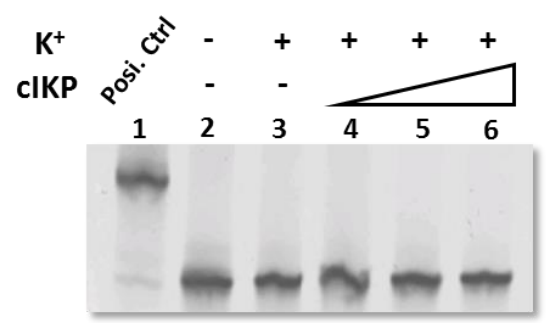

(d) $B C L 2$

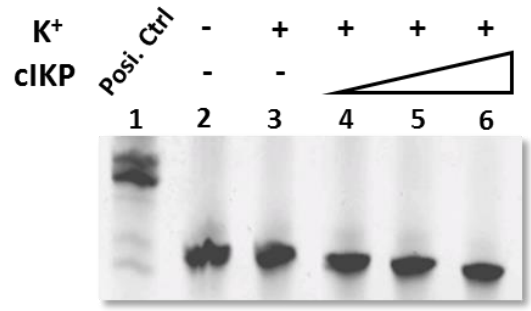

Figure S5. No induction of G4 formation by 1 under no PEG solution by native gel electrophoresis; (a) c-Myc dsDNA, (b) c-kit 1 dsDNA, (c) c-kit 2 dsDNA, (d) BCL2 dsDNA. Lane 1 is a positive control (Posi. Ctrl) for G4 formation bands. Lane 2 shows dsDNA bands as negative controls. Concentrations of 1 are 1,4 , and $16 \mu \mathrm{M}$ for lane 4, 5, and 6 , respectively. 


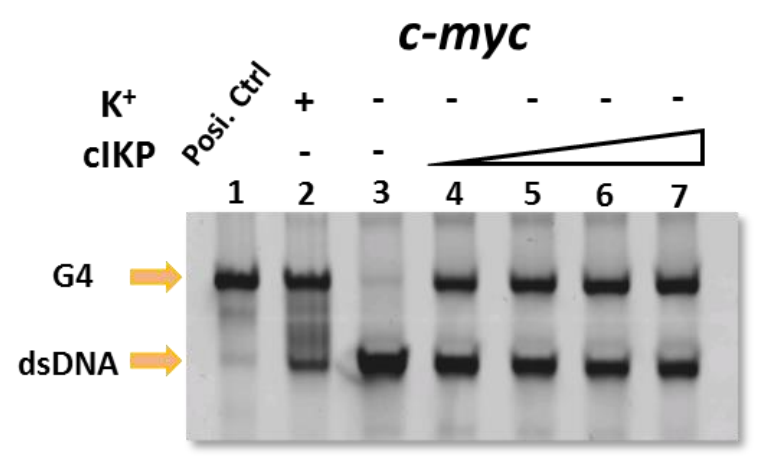

Figure S6. Induction of G4 formation on $c-M y c$ dsDNA by cIKP (1) in the absence of $\mathrm{K}^{+}$ under PEG solution by native gel electrophoresis. Lane 1 is a positive control (Posi. Ctrl) for G4 formation bands. Lane 3 shows dsDNA bands as negative controls. Concentrations of 1 are $1,2,4$, and $8 \mu \mathrm{M}$ for lane $4,5,6$, and 7 , respectively.

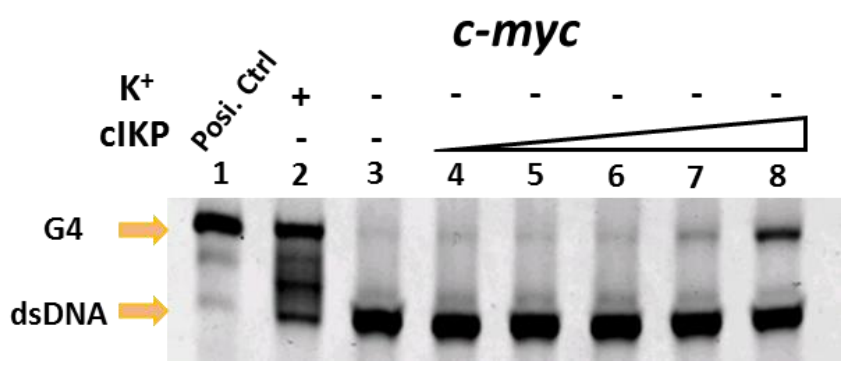

Figure S7. Induction effect of G4 formation on $c-M y c$ dsDNA at the lower concentration ranges of cIKP (1) in the absence of $\mathrm{K}^{+}$under PEG solution by native gel electrophoresis. Lane 1 is a positive control (Posi. Ctrl) for G4 formation bands. Lane 3 shows dsDNA bands as negative controls. Concentrations of $\mathbf{1}$ are 62.5, 125, 250, 500, and $1000 \mathrm{nM}$ for lane 4, 5, 6, 7 , and 8 , respectively. 